\title{
The Proactive-Personality with Curiosity Effects on the Innovative Work Behavior mediated by Work Engagement
}

\author{
Sultan Salem AlShamsi \\ University of Dubai \\ s0000000079@ud.ac.ae
}

\section{Abstract}

There is an abundance of research that supports the relationship between proactive personality and work engagement and between work engagement and innovative work behaviors. However, there has been no study that examined work engagement as a mediator of the relationship between proactive personality and innovative work behaviors. Similarly, there has been no study that examined work engagement as a mediator between the personality traits of curiosity and exploration, with innovative work behaviors

This research examines among other things, the compatibility between proactive personalities of employees, with transformational leadership behaviors of their superiors i.e. the superiorsubordinate fit. It also examines the personality trait of openness to experience as a moderator affecting the dependent variable of innovative work behaviors. This study also investigates the possible moderating effect of transformational leadership on the relationship between proactive personality and work engagement. It is hypothesized that when proactive people have superiors that exhibit transformational leadership behaviors, they become even more engaged in their work. Similarly, employees with personality characteristics of curiosity and exploration, become more engaged when they are working under superiors who practice more transformational leadership behaviors, compared with employees whose superiors exhibit less transformational leadership behaviors. It is finally hypothesized that openness to experience will positively moderate the relationship between work engagement and innovative work behaviors such that people who are more open to experience will exhibit more innovative work behaviors when engaged

At this stage, this represents a conceptual paper. A full quantitative study will be undertaken which will include instruments in the form of self-administered questionnaires distributed among employees involved in the aviation industry in the UAE.

Keywords: Proactive personality, curiosity, and exploration, work engagement, transformational leadership, openness to experience, innovative work behaviors.
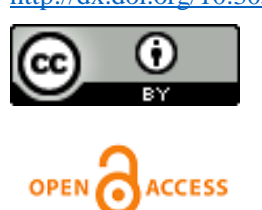

2523-6547 - Copyright: (C) 2017 The Authors. This is an open access article distributed under the terms of the Creative Commons Attribution License, which permits unrestricted use, distribution, and reproduction in any medium, provided the original author and source are credited. 


\section{INTRODUCTION}

\section{Background}

In light of recent tragic events in the aerospace industry, it would seem that there is a need for proactive employees who can forsee and hopefully prevent undesirable events from happening. There is, therefore, a real need for employees to think outside the box, anticipate problems, and engage in innovative work behaviors to prevent problems before they occur. Humans interact between each other under certain environment to achieve a common goal or benefit between each other; where this environment changes comes through those humans who are looking for better way of dealing or living. Proactive-Personality (PP) individuals have the capability to indicate the current situation and then think of about how to change the environment for the benefit for all individual; where that got supported by looking around to find to accumulate the right capabilities and experiences which will helps to change the environment where that exploration process called Curiosity. When the individuals make the required changes for the environment they are working in they harness themselves with the organization under the work role where that called Engagement. Those attachments to the organization might lead the individuals to look for innovative solution which could lead from individuals to think differently and be more innovative

Changes comes through the individuals; those individuals having PP which described as the ability of the individuals to overcome limitations by conditional forces and the capability to affect changes in the environment (Bateman \& Crant, 1993). Moreover, Proactive personalities make change positively to change the surrounded environments initiate positive change in their environments regardless of conditional limitations (Parker, Bindl, \& Strauss, 2010).

The author raised a question about the PP and the innovation; Individuals with a PP have a tendency to be engaged in specific behaviors and perceptions such as career creativity and innovation (Seibert, Kraimer, \& Crant, 2001). The PP type of the individual character as proactive behavior which refers to the actual role of activities in which individuals engage at work (Crant, 2000). Where the work engagement (WE) has two type of actions which lead to the WE; the general action as proactive individual can be as identifying improvement opportunities and challenging the current work status, and more specific actions where the individual will be proactive in such as innovation, socialization, and career management/success (Crant, 2000).

PP helps the employee to have an innovative approach towards improving the environment where one of the specific actions to gain WE that the employee need to be innovative. Innovation Work Behavior (IWB) been defined as the planned formation, introduction and implementation of new ideas within an employee role, internally in groups or on whole organization, in order to improve employee role performance, the group or the organization (Janssen, 2000).

2523-6547 - Copyright: (C 2017 The Authors. This is an open access article distributed under the terms of the Creative Commons Attribution License, which permits unrestricted use, distribution, and reproduction in any medium, provided the original author and source are credited. 
Innovation could be improved by having a curiosity; Curiosity been defined as the desire to accumulate capabilities and experiences which lead the individual to recognize, embrace, and seeks knowledge and new skills or experience. (Kashdan, et al., 2009). If the individual need to have curiosity; the mind should be open to experience; openness to experience as one of the big five factors includes dynamic thoughts, artistic sensitivity, focus to inner emotional state, preference for diversity, and intellectual inquisitiveness (McCrae, 1993-94). Intellectually stimulating followers is one component of the Transformational Leadership (TL) which linked to the creativity and the allowing employees to be innovative; where the leader provides followers with "individualized consideration" and the transformational leader will behave selfsacrificially_(Bass, 1985; Klein \& House, 1995)

This study will focus on the aviation industries which requires continuous proactive approach towards the improvements even in safety or to be effective financially. Moreover, the International Air Transport Association state that the industry supports the livelihoods of 63 million people and underpins \$2.7 trillion of GDP (Annual Review 2016). However, the Air Transport Action Group stated that in 2032, there will be over 6.5 billion passengers and aviation will support 103 million jobs and \$5.8 trillion in economic activity (Aviation Benefits Beyond Borders, 2015, Air Transport Action Group).

Since United Arab Emirates (UAE) play main role in this industry on the middle east; in year 2011 reports shows the aviation sector contributes AED 61.3 billion (6.2\%) to UAE GDP where the aviation sector supports directly 224,000 jobs in the UAE. In addition, there are a further 209,000 people employed through the catalytic (tourism) effects of aviation.

(Economic Benefits from Air Transport in the UAE, 2011). In details of the aviation sector in cities, the overall total economic impact of the aviation sector on the Dubai economy in 2013 can be put at US\$26.7 billion, comprising a 'core' impact of US\$16.5 billion and 'tourism' benefits of US\$10.2 billion. This is equivalent to $26.7 \%$ of Dubai's total GDP, and was sufficient to support some 416,500 jobs or $21 \%$ of Dubai's total employment which could be rise from 26.7\% of Dubai's GDP in 2013 to 37.5\% in 2020 (Quantifying the Economic Impact of Aviation in Dubai November 2014)

The key research question in this study is, "Does the Proactive-Personality affect the Innovative Work Behavior?" The other variables will be studied with association are Curiosity and Exploration, Transformational Leadership and Openness to Experience.

\section{JUSTIFICATION OF THE STUDY}

James Reason in 1990 came with his human error model and management which been famous as swiss cheese model which linked to the aviation industries and other risky industries (Reason, 2000). The swiss cheese model consist of layers of cheese; when the swiss cheese layers' hole's line up together the incident/accident occur. James explain the layers as organizational error (Organizational influences), management error (Unsafe supervision), individual error (unsafe acts), and system error (Preconditions for unsafe) (Reason, 2000). The risk environment which include errors; require from the organization; management; individuals

2523-6547 - Copyright: (C) 2017 The Authors. This is an open access article distributed under the terms of the Creative Commons Attribution License, which permits unrestricted use, distribution, and reproduction in any medium, provided the original author and source are credited. 
to take actions so incidents/accidents will not occur. In the swiss cheese chain of layer (See example below) the individuals located on the last layer; where those individuals are the last people who execute the process.

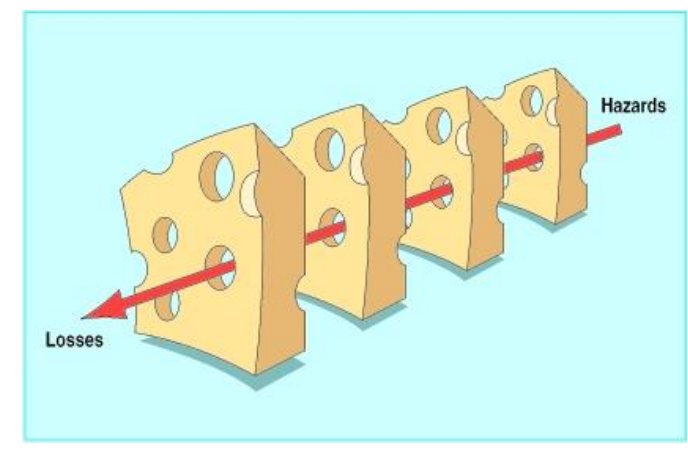

(Reason, 2000)

The proposed justification for the study that PP of individuals will help them to identify the environment they are living in and project the required change towards safer environment by using IWB to propose and adopt the change. Taking innovative initiative to change the environment required the involvement of the leadership who will support the individuals to make the systematic change to stop occurrences; save life; and sustain the company

This research aim to advance understanding of PP with CE and the effects of both of them over the IWB. The research justification that the previous studies highlight the mentioned variables where PP been studied with WE individually; and there is one study which highlight PP with IWB. Moreover; WE been studied with IWB where their author did not find any study which highlight PP, WE, and IWB together

The researcher raises a question about the IWB in the aviation industry specifically in United Arab Emirates (UAE). The aviation industry where based on the safety focus model as main criteria of this industry which the innovation criteria are the late coming criteria in the model. However, as stated earlier on this paper that IWB might have link with the PP which is one of the success factors in the aviation industry which allow the organizations to operate and adapting the changes appear in the industry. Furthermore, the aviation industry requires from the individuals, groups, and organizations to be proactive in safety and in the innovation to accommodate radical improvement which been demanded the aviation globalization of passengers or cargo movement

2523-6547 - Copyright: (C) 2017 The Authors. This is an open access article distributed under the terms of the Creative Commons Attribution License, which permits unrestricted use, distribution, and reproduction in any medium, provided the original author and source are credited. 


\section{LITERATURE REVIEW}

The literature review structured over PP, CE, WE, IWB, TL, and Openness to Experience.

\subsection{Proactive Personality (PP)}

Moreover, what been mentioned previously in this paper as definitions PP; (Crant, 2000) specifically define the PP as behavior where the individual will take initiative to improve the current environment or create new situation which will involve challenging the current status rather than passively adapting to present situations. The proactive individual will look at new opportunities and act to gain the advantages from them; where that lead the individual demonstrate initiative with taking actions and insisting to implement change successfully (Bateman \& Crant, 1993)

PP effects individual ability to change to whatever change in the work situations by taking responsibility for the expansion of personal networks and career development (Hall \& Mirvis, 1995). The new employees take a proactive role in reduction of uncertainty, and to improve behavioral self-management (Chiaburu, Baker, \& Pitariu, 2006)

Moreover, Proactive personalities make change positively to change the surrounded environments initiate positive change in their environments regardless of conditional limitations (Parker, Bindl, \& Strauss, 2010). The PP can be measured to identify the differences between individuals to extent where those individuals will take action based on their environmental situation awareness to influence the improvement (Bateman \& Crant, 1993). The PP individual will make meaningful change after obtain all requirement from the situation; where the non-proactive will be showing the opposite patterns; which will lead the individual to not get benefits from the opportunities (Bateman \& Crant, 1993). Based on the interactionist perspective where the proactive considered that the individual have the possibility to create own environment (Bandura 1977; Schneider 1983)

With regards to the relationship of the big five factors and PP; Openness founded that influences PP since individuals are more likely welling to seek out new knowledge, challenge the gained experiences and which lead the individual likely to accept the situation (Crant \& Bateman, 2000). Extraversion have relation with PP where the individuals with high PP are most likely to be significant and exposed to adopting new behaviors. (Major, Turner, \& Thomas, 2006)

\subsection{Curiosity and Exploration (CE)}

2523-6547 - Copyright: (C) 2017 The Authors. This is an open access article distributed under the terms of the Creative Commons Attribution License, which permits unrestricted use, distribution, and reproduction in any medium, provided the original author and source are credited. 
$\mathrm{CE}$ have been defined in various researches; where Curiosity defined as fundamental motivational source of the reward sensitivity which related to biological base system (Depue, 1996) and central motivation (Ryan \& Deci, 2000), which lead to well-being. Also; Curiosity been described as desire to investigate the originality of information and experiences that require the individual attention (Day, 1971). individuals with better curiosity expand their own knowledge and goal-engagement efforts through seeking innovative information and challenging events (Ainley, Hidi, \& Berndorff, 2002). The researchers highlight the difference between the positive emotions and the Curiosity where Curiosity give attentions to growth and expansion, while enjoyment-related feelings are related to a preference for understanding, effortlessness, and steadiness (Cupchik \& Gebotys, 1990)

The researches findings shows that the curiosity is different from enjoyment where the promising mechanism of curiosity have different of them for example development of wellbeing. (Kashdan, Afram, Brown, Birnbeck, \& Drvoshanov, 2011). Curiosity principally vital to the mindfulness exercise in stimulating or threatening experimental contexts, where this attitude make individuals experiences widely open and accessible to aware attention (Bishop, et al., 2004). The curiosity helps the individuals to embrace the innovation and openness to new experiences (Kashdan T., et al., 2009). The curiosity leads the individual to be attention and have motivation to discover the environment with gratefulness of innovation, challenge, and uncertainty (Gable \& Harmon-Jones, 2009; Silvia \& Kashdan, 2009).

Curiosity is one of the powerful side of human inspiration (Berlyne, 1960; Izard, 1977), where it is a strengths and personality traits of human been studied by psychologists (Peterson \& Seligman, 2004; Reiss, 2000). The human competence cannot be achieved during the absent of sustaining interest; where the importance of the curiosity based on the researches of positive emotions shows that intellectual development at risk when curiosity absent (Tomkins, 1962). Curiosity traits characteristics helps the individual to be interested in new things and enjoying to have an open attitude to things which target and trigger the attention (Bishop, et al., 2004).

People who are curious, they give more attention to an activity where they will process information deeply and recall information better, and are more likely to persist on tasks until goals are met (Silvia \& Litman, 2006). Where one function of curiosity to explore, and learn by engaging on activity which will stimulate and improve the attentional resources (Loewenstein, 1999); where the individual should have self-feeling about the ability to make sense from uncertainty and innovation during explorations process (Sternberg \& Berg, 1985; Spielberger \& Starr, 1994).

Also; the individual curiosity level and the confidence to be curios vary between people which determine the level of willingness to participate in innovation and uncertain nature of everyday life. curiosity helps individuals to be exposed to new information and experience that was not previously available which help to enhance the ability to build new knowledge, skills, relationships, and expertise (Izard, 1977). Curiosity have other role to develop personal intelligence, wisdom, happiness, meaning in life, distress tolerance, and satisfying and engaging social relationships which helps the individual to be engage at work (Renninger, 1992; Silvia \& Litman, 2006).

2523-6547 - Copyright: (C) 2017 The Authors. This is an open access article distributed under the terms of the Creative Commons Attribution License, which permits unrestricted use, distribution, and reproduction in any medium, provided the original author and source are credited. 


\subsection{Work Engagement (WE)}

WE are one of the critical success factors which lead to business success and gain competitive advantage; and that sourced from the Positive psychology influence to increase the human strengths, employee reach to optimal functioning, and attain with sustain employee wellbeing (Luthans \& Peterson, 2002). WE been known as one of the best positive organizational behavior (Macey, Schneider, Barbera, \& Young, 2009). Engagement could be achieved by the investment on physical, intellectual, and emotional energy in work roles which required active "hands, head, \& heart" to achieve full work performance (Ashforth \& Humphrey, 1995; Kahn, 1992)

Where Khan define the WE as harnessing the organisation employee selves to their work role by employing and expressing themselves to physical, intellectual, and emotionally while executing which they employ and express themselves physically, cognitively and emotionally during executing work performances (Kahn, 1990). However; the most accepted related definition was from (Schaufeli, Salanova, Gonzalez-Roma, \& Bakker, 2002) which been described as fulfilling positively the work-related mind characterized by "vigour, dedication, and absorption"

WE refer to the relationship of the employee with his or her work, whereas employee engagement may include a relationship with the organization (Agarwal, 2014). The WE helps the employees to enjoy stable health and have positive affect on work (Demerouti, Bakker, De Jonge, Janssen, \& Schaufeli, 2001; Rothbard, 2001). In 1990 and 1992 in the pioneer work of Kahn's; highlight the antecedents of WE; the worker needs to get more attached to their roles; need to feel safe; and need to be accessible to resources which allow the worker perform as required based on the work role.

\section{H1: PP have positive relationship with WE}

\section{H2: CE have positive relationship with WE}

\subsection{Innovative Work Behavior (IWB)}

IWB been defined as the planned formation, introduction and implementation of new ideas within an employee role, internally in groups or on whole organization, in order to improve employee role performance, the group or the organization (Janssen, 2000). Time pressure serve as influncer for workers to find more efficienct ways with better implementation which motivate the worker use creativity which categories as main driver of innovative work behaviour (Shalley, Gilson, \& Blum, 2000; Unsworth \& Clegg, 2010) (Andrews \& Farris, 1972; Sonnentag, 2003) IWB is claimed to be critical for active functioning and strategic survival of organizations (Amabile, 1979; Kanter, 1988; Shalley, 1995; Van de Ven, 1986). conceive IWB in the workplace as complex behaviour consisting of a set of three different behavioural tasks: idea generation, idea promotion, and idea realization (Perry-Smith \& Shalley, 2003).

IWB considered a individuals contribution into the organizational innovation development; where from the psychological models of innovation there are two stages; first relater to problem identification and idea generation where the second stage related to supporting and application of innovative ideas (Amabile, 1988; West, 2002). IWB purely optional behaviours which lead the IWB to be extra-role behaviours; but IWB are not mentioned clearly that a contract between the employees and the organization where not formally recognized by organizational reward systems (Organ, 1988). However, IWB benefit the organizations which their employees engaged with IWB helps them to perform their job tasks more effectively (Organ, 1988).

2523-6547 - Copyright: (C) 2017 The Authors. This is an open access article distributed under the terms of the Creative Commons Attribution License, which permits unrestricted use, distribution, and reproduction in any medium, provided the original author and source are credited. 


\section{H3: WE have positive relationship with Innovative Work Behavior}

H4: WE have positive mediating effect in relationship between PP with IWB

H5: WE have positive mediating effect in relationship between CE with IWB

\subsection{Openness to Experience (OE)}

The individual builds the experience about the environment construct by relations among sensory, intellectual, and emotional processes; this involves individual bias and awareness which builds once environment (Zeidan, et al., 2011). The openness to experience involves active creativity, artistic sensitivity, attention to inner emotional state, favorite for diversity, and intelligent curiosity (McCrae, 1993-1994). Openness to experience; is one dimension of the five-factor model; which founded that the Openness to experience been accounted by the individuals as which they value in their lives (Dollinger, 199). The most important findings of McCrae's that Openness are in connection with intelligence. (Sacier, 1994) propose that imagination could be the other label for the Openness and intellect which linked to the mental/intellectual exploration.

Individuals with high Openness show the capability to detect, realize, and utilize more information than the individuals with lower Openness (DeYoung, Quilty, Peterson, \& Gray, 2013) Openness to experience where alternatively labeled "Intellectance "which propose that individuals having the motivation to be imaginative, insightful, creative, and thoughtful; where those individuals having the tendency towards change for the better by adapting new approaches toward their environment. (Costa \& McCrae, 1988; DeYoung C. G., 2014). Cognitive processes are part of openness to experience which involve the implicit learning which require detections of connected patterns sensory experience. (DeYoung C. G., 1996)

H7: Openness to Experience have positive Moderating effect in relationship between CE with Innovative WE

\subsection{Transformational Leadership (TL)}

TL motivate, inspire, and encourage their follower to be connected based on their self believe to be align with their group interest and work collectively to achieve the mission (Shamir, House, and Artuher 1993). The concept of TL been coined by JV Downtown in the year 1973 which stated in the Rebel leadership book (Nguni et al, 2006). Furthermore, Burns in his book "Leadership" explain more about the TL, where he emphasis that the TL occurs when leaders engage with followers in such a way that 'leaders and followers raise one another to higher levels of motivation and morality' (Burns, 1978). Moreover, TL has been defined in terms of the leader's self-sacrifice long-term good of the larger group or collective (Waldman et al,. 2005 by Bass, 1985, 1997, 1998; Howell and Avolio, 1992). "The transformational leader's focus is directed toward the organization, and the leader behavior builds follower commitment toward organizational objectives" (Gregory Stone et al,. 2004 by Yukl, 1998).

Furthermore, the TL specified as when the leaders improve the employee's acceptance of the purposes and mission of the organization, and when the leaders motivate the employees to work beyond the employee's self-interest for the good of the group (Gregory Stone et al, 2004 by Bass 1990). Also, TL is about transforming the employee values to support the organization vision and goals by developing an environment of trust in which visions can be shared (Gregory Stone et al,. 2004 by Bass, 1985). In the TL theory development; there are four primary behaviors established that divide TL to Idealized Influence, Inspirational Motivation, Intellectual Stimulation, Individualized Consideration.

2523-6547 - Copyright: (C) 2017 The Authors. This is an open access article distributed under the terms of the Creative Commons Attribution License, which permits unrestricted use, distribution, and reproduction in any medium, provided the original author and source are credited. 
The first is Idealized Influence in which leaders become role models who are well-regarded, appreciated, and emulated by followers and this is the charismatic part of TL (Avolio and Bass, 2002; Bass, 1998; Bass and Avolio, 1994). The most important element of the Idealized influence is the development of a shared vision which is the role of the transformational leader's (Jung and Avolio, 2000). The second element is Inspirational motivation where the transformational leaders inspire and motivate the employee by "providing meaning and challenge to their followers' work" (Avolio and Bass, 2002, p. 2). The transformational leader inspires followers to see forward for the better future, and the leader need to show a pledge towards the group goals and a shared vision (Bass, 1998)

The third element of TL is Intellectual Stimulation, the leader requires to motivate followers' efforts to innovate and be creative to solve the problems and approach the routine in new ways (Avolio and Bass, 2002, p. 2). "The intellectually stimulating leader encourages followers to try new approaches but emphasizes rationality" (Bass, 1990). The fourth element of TL is Individualized Consideration, where the leader will give personal attention to the individual follower's and look at the needs for achievement and growth (Avolio and Bass, 2002). Taking into consideration the followers needs individually the leader could adopt that through effective listening (Avolio and Bass, 2002; Bass, 1998)

H8: TL have positive Moderating effect in relationship between WE with IWB

\section{THEORETICAL DEVELOPMENT AND CONCEPTUAL FRAMEWORK}

A collection of actions from several theories and concepts helps to develop new concept to be studied. The theoretical development having several elements as personal interests; topical research; and base model. The personal interests will explain the researcher source of questions which lead to study this area. The topical research is linked to the personal interest since this was the source for the topic selection for the research. The base mode as theoretical framework where sourced from the topical research since this guide the researcher to find the theories which can be linked to the topical research

\subsection{Personal interests}

The personal interest of the researcher started from the possibility to measure the futurist effectiveness where there was no defined research or questionnaire can highlight the fundamentals of this topic; and that lead the researcher to think one step back about the personal who make the change based on the environmental understanding and the requirement for improvement to benefit the people who lives on that environment. The research's highlight that personal having a PP which collect the necessary information from the surrounding environment and make the change to benefit the people who lives on that environment.

2523-6547 - Copyright: (C) 2017 The Authors. This is an open access article distributed under the terms of the Creative Commons Attribution License, which permits unrestricted use, distribution, and reproduction in any medium, provided the original author and source are credited. 


\subsection{Topical research}

The topical research is the PP and IWB; where that linked to idea been developed from the personal interest of the researcher. The topical research is the one which will help to explore the area where will help to know if the selected variables having the effects on each other, and if that will help to understand the area of PP. Furthermore; the topical research will allow the researcher to explore the areas which related to the WE and the relationship with the IWB.

\subsection{Theoretical (Base Model) framework}

From the topical research and the selected variables; there are theories which shape the theoretical framework. The researcher come across those theories in relation to this study:

1. Social Learning Theory: Bandura, Albert (1977) - PP

2. Curiosity Theory: Blarer (1951) in the book Die Neugier

3. Attachment Theory: Bowlby, J. (1969) - Work Engagement

4. Five-Factor Model (FFT; McCrae \& Costa, 1996, 1999) - Openness to Experience

5. The TL Theory: Bass and Avolio in the year 1985.

6. Innovation Work Behavior (Bateman and Crant, 1993)

\subsection{Conceptual Framework}

In Table1; different studies show the relationship between the variables mentioned in the literature review. Two studies show the positive relationship between PP and WE (Drown, 2013; Josje Et, Al. 2010). Other study shows a positive relationship between the PP and IWB (Ellen Et, Al. 2016). Where (Agarwal Et, Al. 2012; Agarwal, 2014) studied the relationship between the relation between the leadership, WE and IWB.

Several studies indicated the relationship between the openness to experience and curiosity; the curiosity has a positive correlation with openness to experience and help the individual to except looking for different means of ideas and solutions (Hough, L. \& Ones, D.; 2001, Woo et, al.; 2014, Woo et, al.; 2015). The Relationship between Leader-Member Exchange and Innovative Work Behaviour been studied by several researchers which shows a positive relationship between those two variables (Suhaimi \& Panatik, 2016).

Other study highlight that transformational and transactional leadership positively predicted IWB (Khan, Aslam, \& Riaz, 2012). The TL and IWB have positive relationship mediated by other variables like leaders' active empathetic listening (Sharifirad, 2013)

2523-6547 - Copyright: (C) 2017 The Authors. This is an open access article distributed under the terms of the Creative Commons Attribution License, which permits unrestricted use, distribution, and reproduction in any medium, provided the original author and source are credited. 


\section{Table. 1}

\begin{tabular}{|c|c|c|c|}
\hline $\begin{array}{l}\text { Independent } \\
\text { Variable }\end{array}$ & Intervening Variable & Dependent Variable & Author \\
\hline PP & $\begin{array}{l}\text { Work Design } \\
\text { Characteristics }\end{array}$ & Engagement & Drown, 2013 \\
\hline Job Characteristics & $\mathrm{PP}$ & Engagement & Josje Et, Al. 2010 \\
\hline PP & $\begin{array}{l}\text { Task Conflict } \\
\text { Job Autonomy }\end{array}$ & Innovative Behavior & Ellen Et, Al. 2016 \\
\hline $\begin{array}{l}\text { Job Insecurity } \\
\text { Job Autonomy }\end{array}$ & Work Engagement & $\begin{array}{l}\text { Innovative Work } \\
\text { Behavior }\end{array}$ & $\begin{array}{l}\text { De Spiegelaere Et, Al. } \\
2014\end{array}$ \\
\hline LMX & Work Engagement & $\begin{array}{l}\text { Innovative Work } \\
\text { Behaviour } \\
\text { Turnover Intentions }\end{array}$ & Agarwal Et, Al. 2012 \\
\hline $\begin{array}{l}\text { Leader-Member } \\
\text { Exchange } \\
\text { Perceived } \\
\text { Organizational } \\
\text { Support }\end{array}$ & Engagement on Employees & $\begin{array}{l}\text { Innovative Work } \\
\text { Behavior }\end{array}$ & Agarwal, 2014 \\
\hline $\begin{array}{l}\text { Autonomy } \\
\text { Strategic Attention } \\
\text { Role Benefit }\end{array}$ & Engagement & Innovative Behavior & $\begin{array}{l}\text { Slatten \& Mehmetoglu, } \\
2012\end{array}$ \\
\hline $\begin{array}{l}\text { Psychological } \\
\text { Contract Fulfillment } \\
\text { Procedural Justice } \\
\text { Interactional Justice }\end{array}$ & $\begin{array}{l}\text { Trust } \\
\text { Work Engagement }\end{array}$ & $\begin{array}{l}\text { Innovative Work } \\
\text { Behaviour }\end{array}$ & Agarwal, 2014 \\
\hline
\end{tabular}

Based on the literature review findings and literature gap; the researcher drafts the initial conceptual framework. This conceptual framework shows the relationship between the variables in the study; there are some relationship been studied in previous researches

\section{Conceptual Framework:}




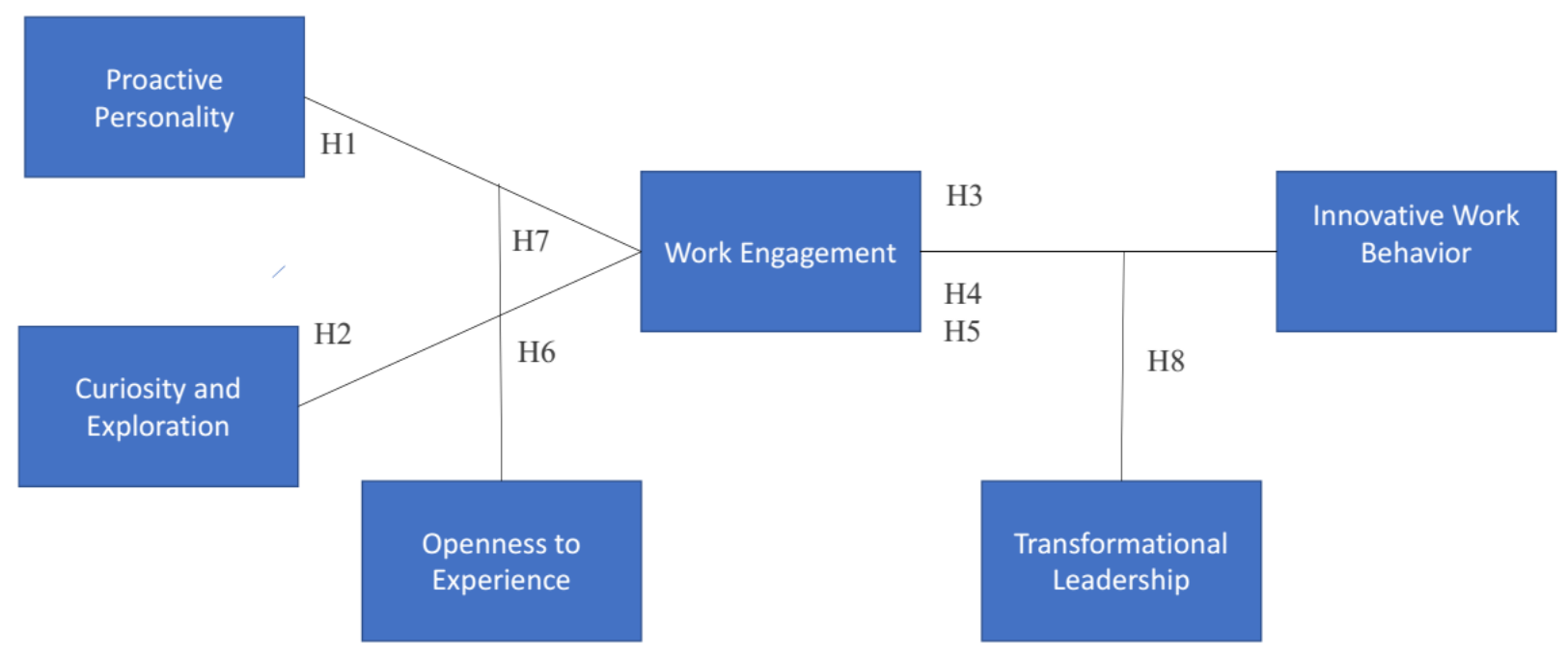

\subsection{Theoretical contribution}

From the literature review and gap analysis of the previous studies; the researcher based the presented conceptual framework on the previous studies. Furthermore; Curiosity and WE relationship not indicated in any study previously where consider first theoretical contribution. The second theoretical contribution is to study the mediating effect of WE between PP and IWB. The third theoretical contribution is to study the moderating effect of openness to experience between PP and WE. The fourth theoretical contribution is to study the moderating effect of TL between WE and IWB. The fifth theoretical contribution is to study the moderating effect of openness to experience between curiosity and WE. 


\section{References}

1. Agarwal, U. A. (2014). Examining the impact of social exchange relationships on innovative work behaviour: Role of work engagement. Team Performance Management, 102-120.

2. Ainley, M., Hidi, S., \& Berndorff, D. (2002). Interest, Learning, and the Psychological Processes That Mediate Their Relationship. Journal of Educational Psychology, 545-561.

3. Amabile, T. M. (1979). Effects of external evaluation on artistic creativity. Journal of Personality and Social Psychology, 221-233.

4. Amabile, T. M. (1988). A model of creativity and innovation in organizations. Research in organizational behavior, 123-167.

5. Andrews, F. M., \& Farris, G. F. (1972). Time pressure and performance of scientists and engineers: A five year panel study. Organizational Behavior and Human Performance, 185-200.

6. Ashforth, B. E., \& Humphrey, R. H. (1995). Emotion in the workplace: A reappraisal. Human Relations, 97-125.

7. Bass, B. M. (1985). Leadership: Good, better, best. Organizational dynamics, 26-40.

8. Bateman, T. S., \& Crant, J. M. (1993). The proactive component of organizational behavior: A measure and correlates. Journal of Organizational Behaviour, 103-118.

9. Berlyne, D. E. (1960). Conflict, Arousal and Curiosity. New York: McGraw-Hill Publishing Company Ltd.

10. Bishop, S. R., Lau, M., Shapiro, S., Carlson, L., Anderson, N. D., Carmody, J., . . Devins, G. (2004). Mindfulness: A Proposed Operational Definition. Clinical Psychology: Science and Practice, 230-241.

11. Chiaburu, D. S., Baker, V. L., \& Pitariu, A. H. (2006). Beyond being proactive: what (else) matters for career self-management behaviors? Career Development International, 619-632.

12. Costa, P. T., \& McCrae, R. R. (1988). From catalog to classification: Murray's needs and the fivefactor model. Journal cf Personality and Social Psychology, 258-265.

13. Crant, M. J. (2000). Proactive Behavior in Organizations. Journal of Management, 435-462.

14. Crant, M. J., \& Bateman, T. S. (2000). Charismatic leadership viewed from above: The impact of PP. Journal of Organizational Behavior, 63-75.

15. Cupchik, G. C., \& Gebotys, R. J. (1990). Interest and pleasure as dimensions of aesthetic experience. Empirical Studies of the Arts, 1-14.

16. Day, H. I. (1971). The measurement of specific curiosity. In H. Day, D. Berlyne, \& D. Hunt, Intrinsic motivation: A new direction in Education. Toronto: Rinehart \& Winston of Canada.

17. Demerouti, E., Bakker, A. B., De Jonge, J., Janssen, P., \& Schaufeli, W. B. (2001). Burnout and engagement at work as a function of demands and control. Scandinavian Journal of Work, Environment \& Health, 567-589. 
18. Depue, R. A. (1996). A neurobiological framework for the structure of personality and emotion: Implications for personality disorders. In J. F. Clarkin, \& M. F. Lenzenweger, Major theories of personality disorder (pp. 347-390). New York: Guilford.

19. DeYoung, C. G. (1996). Social consequences of experiential openness. Psychological Bulletin, 323-337.

20. DeYoung, C. G. (2014). Openness/Intellect: A dimension of personality reflecting cognitive. In M. L. Cooper, \& R. J. Larsen, APA handbook of personality and social (pp. 369-399). Washington: American Psychological Association.

21. DeYoung, G. C., Quilty, C. L., Peterson, B. J., \& Gray, R. J. (2013). Openness to Experience, Intellect, and Cognitive Ability. Journal of Personality Assessment, 1-7.

22. DOLLINGER, S. J. (1996). On Traits and Values: With Special Reference to Openness to Experience. JOURNAL OF RESEARCH IN PERSONALITY, 23-41.

23. Gable, P. A., \& Harmon-Jones, E. (2009). Neural activity underlying the effect of approachmotivated positive affect on narrowed attention. Psychological Science, 406-409.

24. Hall, D. T., \& Mirvis, P. H. (n.d.).

25. Hall, D. T., \& Mirvis, P. H. (1995). The new career contract: developing the whole person at midlife and beyond. Journal of Vocational Behavior, 269-289.

26. Izard, C. E. (1977). Human Emotions. New York: Plenum.

27. Janssen, O. (2000). Job demands, perceptions of effort-reward fairness and innovative work behaviour. Journal of Occupational and Organizational Psychology, 287-302.

28. Kahn, W. A. (1990). Psychological conditions of personal engagement and disengagement at work. Academy of Management Journal, 692-724.

29. Kahn, W. A. (1992). To be full there: psychological presence at work. Human Relations, 321-349.

30. Kanter, R. M. (1988). Three tiers for innovation research. Communication Research, 509-523.

31. Kashdan, T. B., Afram, A., Brown, K. W., Birnbeck, M., \& Drvoshanov, M. (2011). Curiosity enhances the role of mindfulness in reducing defensive responses. Personality and Individual Differences, 1227-1232.

32. Kashdan, T. B., Gallagher, M. W., Silvia, P. J., Breen, W. E., Terhar, \& Terhar, D. (2009). The Curiosity and Exploration Inventory-II: Development, factor. Journal of Research in Personality, 987-998.

33. Kashdan, T., Gallagher, M., Silvia, P., Winterstein, B., Breen, W., Terhar, D., \& Steger, M. (2009). The curiosity and exploration inventory-II: Development, factor structure, and psychometrics. Journal of Research in Personality, 987-998.

34. Khan, M. J., Aslam, N., \& Riaz, M. N. (2012). Leadership Styles as Predictors of Innovative Work Behavior. Pakistan Journal of Social and Clinical Psychology, 17-22.

2523-6547 - Copyright: (C) 2017 The Authors. This is an open access article distributed under the terms of the Creative Commons Attribution License, which permits unrestricted use, distribution, and reproduction in any medium, provided the original author and source are credited. 
35. Klein, K. J., \& House, R. J. (1995). On fire: Charismatic leadership and levels of analysis. The Leadership Quarterly, 183-198.

36. Loewenstein, G. (1999). Because it is there: The challenge of mountaineering... for utility theory. Kyklos, 315-344.

37. Luthans, F., \& Peterson, S. J. (2002). Employee engagement and manager self-efficacy. Journal of Management Development, 376 - 387.

38. Macey, W. H., Schneider, B., Barbera, K. M., \& Young, S. A. (2009). Employee Engagement: Tools for Analysis, Practice, and Competitive. West Sussex: John Wiley \& Sons.

39. Major, D. A., Turner, J. E., \& Thomas, D. (2006). Linking PP and the Big Five to Motivation to Learn and Development Activity. Journal of Applied Psychology, 927-935.

40. McCrae, R. R. (1993-1994). Openness to Experience as a basic dimension of personality. Imagination, Cognition and Personality, 39-55.

41. McCRAE, R. R. (1993-94). OPENNESS TO EXPERIENCE AS A BASIC DIMENSION OF PERSONALITY. IMAGINATION, COGNITION AND PERSONALITY, 39-55.

42. Organ, D. W. (1988). Organizational Citizenship Behavior: The Good Soldier Syndrome. Lexington, MA: Lexington Books.

43. Parker, S. K., Bindl, U. K., \& Strauss, K. (2010). Making Things Happen: A Model of Proactive Motivation . the Journal of Management, 827-856.

44. Perry-Smith, J. E., \& Shalley, C. E. (2003). The Social Side of Creativity: A Static and Dynamic Social Network Perspective. The Academy of Management Review, 89-106.

45. Peterson, C., \& Seligman , M. (2004). Character strengths and virtues: A handbook and classification. Reiss S. Who am I? The 16 basic desires that motivate our actions and define our personalities. New York: Tarcher/Putnum; 2000., 125-141.

46. Reason, J. (2000). Human error: models and management. BMJ Journal, 768-770.

47. Reiss, S. (2000). Who am I? The 16 basic desires that motivate our actions and define our personalities. New York: Tarcher/Putnum.

48. Renninger, K. A. (1992). Individual interest and development: implications for theory and practice. In K. A. Renninger, S. Hidi, \& A. Krapp, The role of interest in learning and development. (pp. 361-395). Hillsdale, NJ: Erlbaum.

49. Rothbard, N. P. (2001). Enriching or depleting? The dynamics of engagement in work and family roles. Administrative Science Quarterly, 655-84.

50. Ryan, R. M., \& Deci, E. L. (2000). Intrinsic and Extrinsic Motivations: Classic Definitions and New Directions. Contemporary Educational Psychology, 54-67.

51. Sacier, G. (1994). Journal of Personality Assessment, 506-516.

2523-6547 - Copyright: (C) 2017 The Authors. This is an open access article distributed under the terms of the Creative Commons Attribution License, which permits unrestricted use, distribution, and reproduction in any medium, provided the original author and source are credited. 
52. Schaufeli, W. B., Salanova, M., Gonzalez-Roma, V., \& Bakker, A. B. (2002). The measurement of engagement and burnout: a two sample confirmatory factor analytic approach. Journal of Happiness Studies, 71-92.

53. Scott, S. G., \& Bruce, R. A. (1994). Determinants of innovative behavior: A path model of individual

innovation in the workplace. Academy of Management Journal, 37, 580-607

54. Seibert, S. E., Kraimer, M. L., \& Crant, J. M. (2001). What do proactive people do? A longitudinal model linking PP and career success. Personnel Psychology, 845-874.

55. Shalley, C. E. (1995). Effects of coaction, expected evaluation, and goal setting on creativity and productivity. Academy of Management Journal, 483-503.

56. Shalley, C. E., Gilson, L., \& Blum, T. C. (2000). Matching creativity requirements and the work environment: Effects on satisfaction and intentions to leave. Academy of Management Journal, 215-223.

57. Sharifirad, M. S. (2013). Transformational leadership, innovative work behavior, and employee well-being. Global Business Perspectives, 198-225.

58. Silvia, P. J., \& Kashdan, T. B. (2009). Interesting Things and Curious People: Exploration and Engagement as Transient States and Enduring Strengths. Social and Personality Psychology Compass, 785-797.

59. Silvia, P. J., Litman, J. A., \& . (2006). The latent structure of trait curiosity: Evidence for interest and deprivation curiosity dimensions. Journal of Personality Assessment, 318-328.

60. Sonnentag, S. (2003). Recovery, work engagement, and proactive behavior: A new look at the interface between nonwork and work. Journal of Applied Psychology, 518-528.

61. Spielberger, C. D., \& Starr, L. M. (1994). Motivation: Theory and research. In H. F. O’Neil, \& M. Drillings, Curiosity and exploratory behavior (pp. 221-243). Hillsdale: Lawrence Erlbaum Associates, Inc.

62. Sternberg, R. J., \& Berg, C. A. (1985). A triarchic theory of intellectual development during adulthood. Developmental Review, 334-370.

63. Suhaimi, I. W., \& Panatik, S. A. (2016). A LITERATURE REVIEW ON RELATIONSHIP BETWEEN LEADER-MEMBER EXCHANGE AND INNOVATIVE WORK BEHAVIOUR. Journal of Global Business and Social Entrepreneurship, 32-41.

64. Tomkins, S. (1962). Affect Imagery Consciousness. Vol I: The Positive Affects. New York: Springer.

65. Unsworth, L. K., \& Clegg, C. W. (2010). Why Do Employees Undertake Creative Action? JOURNAL OF OCCUPATIONAL \& ORGANIZATIONAL PSYCHOLOGY, 1-44.

66. Van de Ven, A. H. (1986). Central problems in the management of innovation. Journal of Management science, 590-607.

67. West, M. A. (2002). Ideas are ten a penny: It's team implementation not idea generation that counts. Applied Psychology: An International Review, 411-424.

2523-6547 - Copyright: (C) 2017 The Authors. This is an open access article distributed under the terms of the Creative Commons Attribution License, which permits unrestricted use, distribution, and reproduction in any medium, provided the original author and source are credited. 
68. Zeidan, F., Martucci, K. T., Kraft, R. A., Gordon, N. S., McHaffie, J. G., \& Coghill, R. C. (2011). Brain mechanisms supporting the modulation of pain by mindfulness meditation. The Journal of Neuroscience, 5540-5548. 